Nat. Hazards Earth Syst. Sci., 18, 2355-2366, 2018

https://doi.org/10.5194/nhess-18-2355-2018

(C) Author(s) 2018. This work is distributed under

the Creative Commons Attribution 4.0 License.

\title{
Growth of a sinkhole in a seismic zone of the northern Apennines (Italy)
}

\author{
Alessandro La Rosa ${ }^{1,2}$, Carolina Pagli ${ }^{2}$, Giancarlo Molli ${ }^{2}$, Francesco Casu ${ }^{3}$, Claudio De Luca ${ }^{3}$, Amerino Pieroni ${ }^{4}$, and \\ Giacomo D'Amato Avanzi ${ }^{2}$ \\ ${ }^{1}$ Dipartimento di Scienze della Terra, Università degli Studi di Firenze, Via G. La Pira, 4, 50121 Florence, Italy \\ ${ }^{2}$ Dipartimento di Scienze della Terra, Università di Pisa, Via S. Maria, 53, 56126 Pisa, Italy \\ ${ }^{3} \mathrm{CNR}$, Consiglio Nazionale delle Ricerche, Istituto per il Rilevamento Elettromagnetico dell'Ambiente (IREA-CNR), \\ Via Diocleziano, 328, 80124 Naples, Italy \\ ${ }^{4}$ Pro.Geo. s.r.l. Via Valmaira, 14, 55032, Castelnuovo di Garfagnana, Italy
}

Correspondence: Alessandro La Rosa (alessandro.larosa@unifi.it)

Received: 19 March 2018 - Discussion started: 26 March 2018

Revised: 31 July 2018 - Accepted: 17 August 2018 - Published: 12 September 2018

\begin{abstract}
Sinkhole collapse is a major hazard causing substantial social and economic losses. However, the surface deformations and sinkhole evolution are rarely recorded, as these sites are known mainly after a collapse, making the assessment of sinkhole-related hazard challenging. Furthermore, more than $40 \%$ of the sinkholes of Italy are in seismically hazardous zones; it remains unclear whether seismicity may trigger sinkhole collapse. Here we use a multidisciplinary data set of InSAR, surface mapping and historical records of sinkhole activity to show that the Prà di Lama lake is a long-lived sinkhole that was formed in an active fault zone and grew through several events of unrest characterized by episodic subsidence and lake-level changes. Moreover, InSAR shows that continuous aseismic subsidence at rates of up to $7.1 \mathrm{~mm} \mathrm{yr}^{-1}$ occurred during 2003-2008, between events of unrest. Earthquakes on the major faults near the sinkhole do not trigger sinkhole activity but low-magnitude earthquakes at 4-12 km depth occurred during sinkhole unrest in 1996 and 2016. We interpret our observations as evidence of seismic creep at depth causing fracturing and ultimately leading to the formation and growth of the Prà di Lama sinkhole.
\end{abstract}

\section{Introduction}

Sinkholes are closed depressions with internal drainage typically associated with karst environments, where the exposed soluble rocks are dissolved by circulating groundwater (dissolution sinkholes) but other types of sinkholes also exist. Subsidence sinkholes, for example, can form for both internal erosion and dissolution of covered layers leading to downward gravitational deformations such as collapse, sagging or suffosion (Ford and Williams, 2007; Gutiérrez et al., 2008). Deep sinkholes have been often observed along seismically active faults indicating a causal link between sinkhole formation and active tectonics (Faccenna et al., 1993; Harrison et al., 2002; Closson et al., 2005; Florea, 2005; Del Prete et al., 2010; Parise et al., 2010; Wadas et al., 2017). In some cases, the processes responsible for their formation have been attributed to fracturing and increased permeability in the fault damage zone, promoting fluid circulation and weathering of soluble rocks at depth. Additionally, when carbonate bedrocks lie below thick non-carbonate formations, stress changes caused by faulting may cause decompression of confined aquifers favouring upward migration of deep fluids, hence promoting erosion and collapses (e.g. Harrison et al., 2002; Wadas et al., 2017). Seismically induced stress changes could also trigger the collapse of unstable cavities as in the case of the two sinkholes that formed near Ein Gedi (Dead Sea) following the $M_{\mathrm{w}} 5.2$ earthquake on the Dead Sea Transform fault in 2004 (Salamon, 2004). Sinkhole subsidence and collapses are a major hazard and cause substan- 
tial economic and human losses globally (Frumkin and Raz, 2001; Closson, 2005; Wadas et al., 2017).

In Italy, a total of 750 sinkholes have been identified and the $40 \%$ of them are along active faults (Caramanna et al., 2008) but this number could be underestimated due to the high frequency of sinkholes both related to karst and anthropogenic origin (Parise and Vennari, 2013). Seismicityinduced sinkhole deformation has been often observed in Italy (e.g. Santo et al., 2007; Parise et al., 2010; Kawashima et al., 2010).

The sinkhole of Prà di Lama, near the village of Pieve Fosciana (Lucca province, Italy), is a quasi-circular depression filled by a lake. Prà di Lama is located in the seismically active Apennines range of northern Tuscany, at the intersection of two active faults (Fig. 1). Hot springs are also present at Pieve Fosciana suggesting that fluid migration occurs along the faults planes. Sudden lake-level changes of up to several metres, ground subsidence, surface fracturing and seismicity have occurred repeatedly since at least $991 \mathrm{AD}$ (Nisio, 2008). The most recent deformation events occurred in March 1996 and between May 2016 and October 2017. However, the processes that control the growth of the Prà di Lama sinkhole remain unclear. Furthermore, whether seismicity along the active faults around Prà di Lama may trigger sinkhole subsidence or collapse is debated.

In this paper we combine recent InSAR observations, seismicity and surface mapping, as well as historical records of lake-level changes and ground subsidence at the Prà di Lama from 1828 to understand the mechanisms of sinkhole growth in an active fault system.

\section{Geological setting}

The area of the Prà di Lama sinkhole is located within the Garfagnana basin (Fig. 1), an extensional graben in the northwestern Apennines, a NW-SE-trending fold-and-thrust belt formed by the stack of different tectonic units caused by the convergence of the Corsica-European and Adriatic plates. The current tectonic regime of the Apennines is characterized by shortening in the eastern sector of the Apennines range and extension in the westernmost side of the range (Elter et al., 1975; Patacca and Scandone, 1989; Bennett et al., 2012). The contemporaneous eastward migration of shortening and upper plate extension are believed to be caused by the roll-back subduction during the anticlockwise rotation of the Adriatic plate (Doglioni, 1991; Meletti et al., 2000; Serpelloni et al., 2005; Faccenna et al., 2014; Le Breton et al., 2017). Extension started 4-5 Ma, leading to the formation of several NW-SE-oriented grabens, bounded by NE-dipping and SW-dipping normal faults that are dissected by several NE-trending, right-lateral strike-slip faults (Fig. 1). The inner northern Apennines are a seismically active area, where several earthquakes with $M_{\mathrm{w}}>5$ occurred, including the largest instrumentally recorded earthquake, $M_{\mathrm{w}} 6.5$, in 1920 (Tertul-

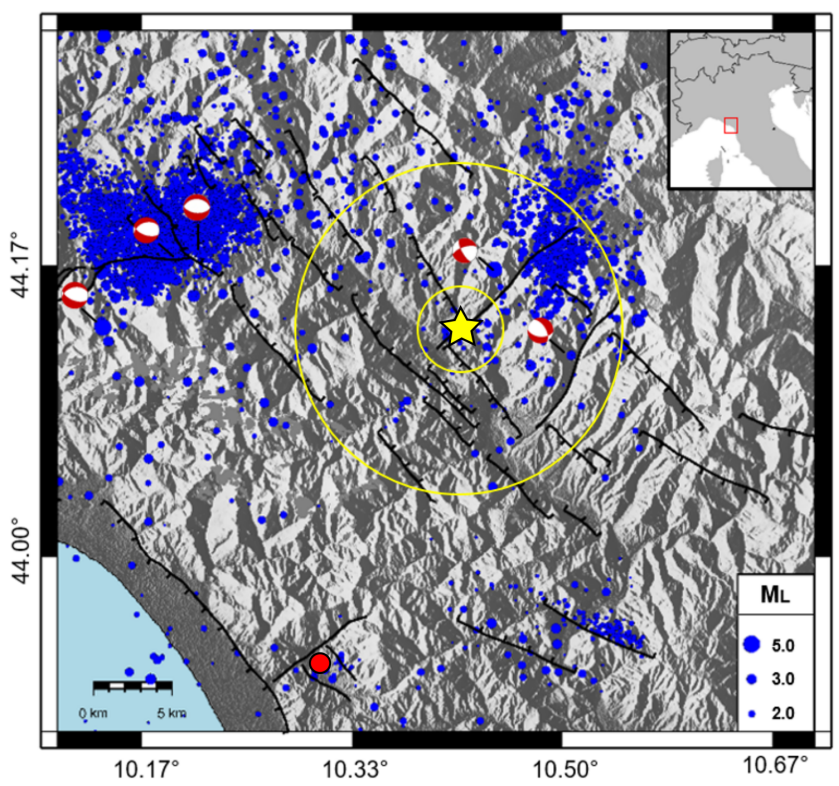

Figure 1. Study area: the Prà di Lama sinkhole is marked by the yellow star. Black tick lines are faults. Blue dots are the earthquakes between 1986 and 2017. Focal mechanisms are from the Regional Centroid Moment Tensor (RCMT) catalogue. The yellow circles represent the areas with radii of 3 and $10 \mathrm{~km}$ used for the seismicity analysis. The red dot is the Camaiore sinkhole (Buchignani et al., 2008; Caramanna et al., 2008). The red box in the inset marks the location of the area shown in the main figure.

liani and Maramai, 1998; Rovida et al., 2016; Bonini et al., 2016) and the most recent $M_{\mathrm{W}} 5.1$ earthquake in 2013 (Pezzo et al., 2014; Stramondo et al., 2014; Molli et al., 2016).

The uppermost stratigraphy at Prà di Lama consists of $8 \mathrm{~m}$ thick layer of alluvial and palustrine gravels and sandy deposits containing peaty levels, covering an $\sim 85 \mathrm{~m}$ thick sandy-to-silty fluviolacustrine deposits with low permeability (from Villafranchian to present age) (Chetoni, unpublished data) (Fig. 2a and b). These deposits cover a $\sim 1000 \mathrm{~m}$ thick turbiditic sequence (Macigno Formation). Below it, a sequence of carbonate rocks pertaining to the Tuscan Nappe unit is present reaching down to a depth of $\sim 2000 \mathrm{~m}$, where anhydrites (Burano Formation) and calcareous-dolomitic breccias (Calcare Cavernoso Formation) overlie the Tuscan Metamorphic units (Fig. 2c).

The Prà di Lama lake lies at the centre of a depression (Figs. 2 and 5). The low slopes characterizing the topography of the area result in the absence of active gravitational ground motions (Fig. 2). Furthermore, the Prà di Lama sinkhole is an isolated feature in the region, being the only mapped sinkhole in the entire Garfagnana graben (Caramanna et al., 2008); the closest sinkhole is in Camaiore (Buchignani et al., 2008) near the Tuscany coast (Fig. 1). 

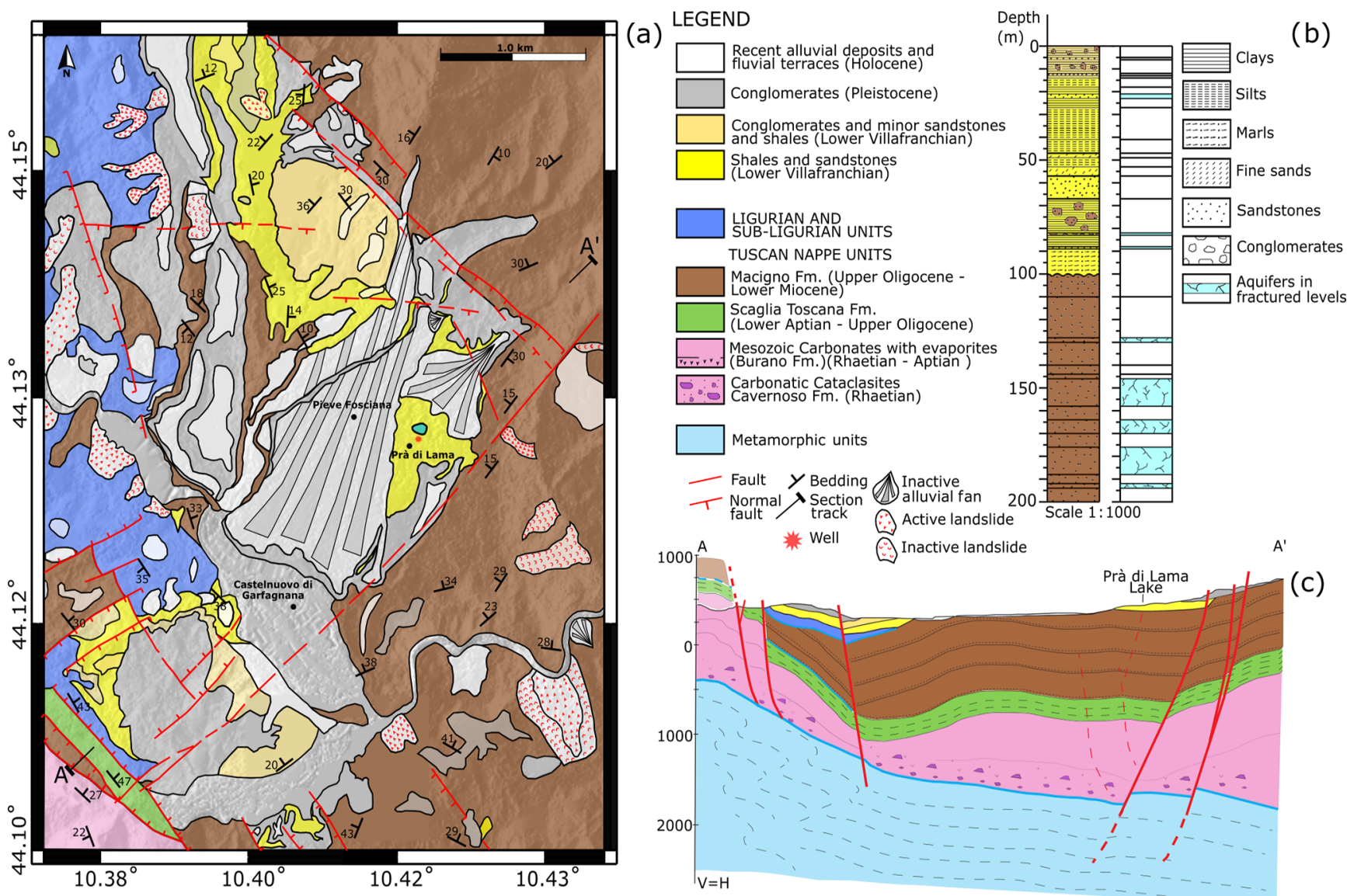

Figure 2. Geological setting of the study area. (a) Geological, structural and geomorphological map of the area nearby Prà di Lama showing the main tectonic and lithostratigraphic units. (b) Schematic sedimentary sequence of the Villafranchian deposits obtained from the well drilled at Prà di Lama (modified from Chetoni, unpublished data). (c) Stratigraphic cross section across the Garfagnana graben.

The Prà di Lama sinkhole is located at the intersection between two seismically active faults: the Corfino normal fault (Di Naccio et al., 2013; ISIDe working group, 2016) and the right-lateral strike-slip M. Perpoli-T. Scoltenna fault that recently generated the $M_{\mathrm{w}} 4.8$ earthquake in January 2013 (Fig. 1) (Pinelli, 2013; Molli et al., 2017). Hot water springs are also present at Prà di Lama (Bencini et al., 1977; Gherardi and Pierotti, 2018). Geochemical analyses of the Prà di Lama spring waters by Gherardi and Pierotti (2018), expanding on previous research (Baldacci et al., 2007), suggest that both shallow and deep aquifers are present below Prà di Lama (Fig. 2b). Shallow aquifers have low salinity and low temperature, while waters feeding the thermal springs have high temperature $\left(\sim 57^{\circ} \mathrm{C}\right)$ and high salinity $\left(5.9 \mathrm{~g} \mathrm{kgw}^{-1}\right)$, suggesting the presence of a deep aquifer at $\sim 2000 \mathrm{~m}$ into the anhydrite and the calcareous-dolomitic breccia. The high salinity of the deep groundwaters is associated with dissolution of the deep evaporitic formations. Furthermore, unmixing of deep and shallow waters is interpreted by Gherardi and Pierotti (2018) as evidence of their rapid upwelling, likely occurring along the existing faults.

\section{Data}

Century-scale historical records of sinkhole activity are available at Prà di Lama and allow us to determine the timescale of sinkhole evolution as well as to characterize the different events of unrest, in particular the two most recent events in 1996 and 2016. InSAR time series analysis is also carried out to measure ground deformations in the Prà di Lama sinkhole in the time period between events of unrest. Finally, the local catalogue of seismicity (ISIDE catalogue, INGV) is used to inform us on the timing and types of brittle failures in the area of the sinkhole.

\subsection{Historical record}

The first historical record of the Prà di Lama sinkhole dates back to the $991 \mathrm{AD}$, when the area was described as a seasonal shallow pool fed by springs. Since then, the depression grew and several events of unrest consisting of fracturing and fluctuations of the lake level were reported (Raffaelli, 1869; De Stefani, 1879, Giovannetti, 1975) (Table 1). In particular, eight events of unrest were reported, giving an average 


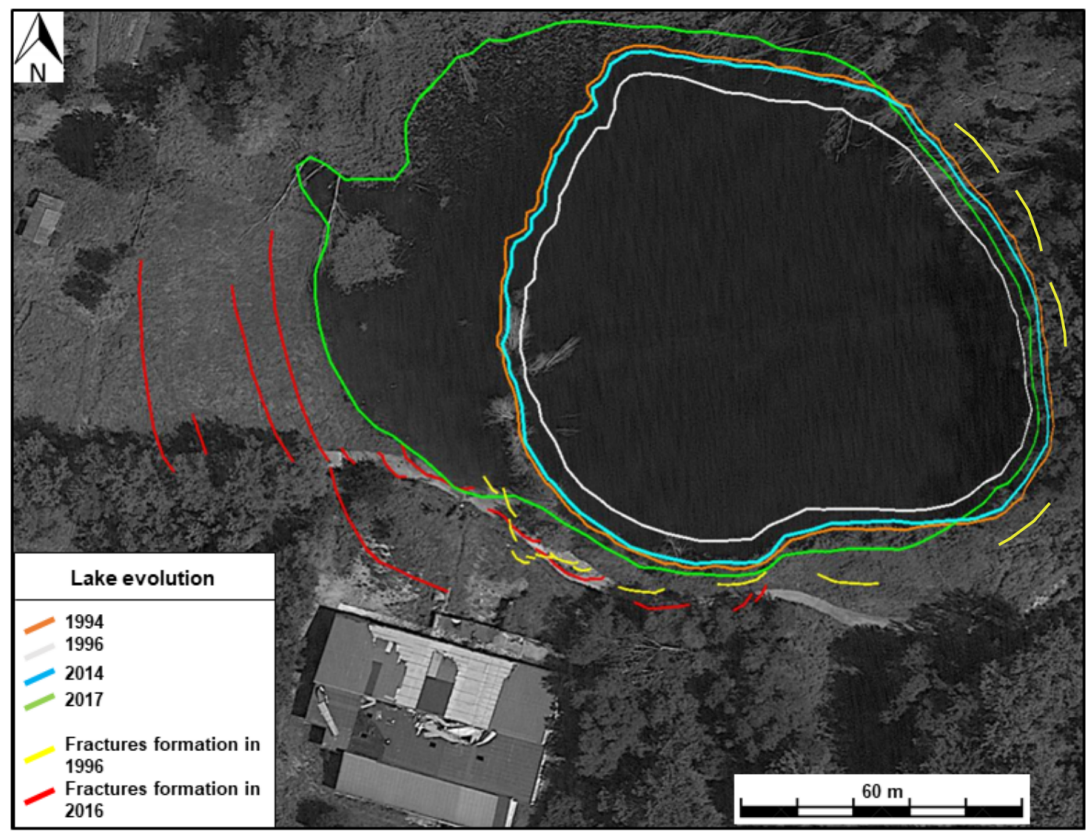

Figure 3. Evolution of the Prà di Lama lake between 1994 and 2017. Lake shore variation has been retrieved from the analysis of the Landsat image.

of 1 event of unrest every 26 years. We conducted direct observation of surface deformation around the lake for the two most recent events in 1996 and 2016.

In 1996, the lake level experienced a fall of up to $4 \mathrm{~m}$ (Figs. 3 and S1 in the Supplement) and at the same time the springs outside the lake suddenly increased the water outflow. Clay and mud were also ejected by the springs outside the lake, while fractures and slumps occurred within the lake due to the water drop (Figs. 3 and S1). The unrest lasted approximately 2 months, from March to April 1996. During the final stages, the water level in the lake rose rapidly, recovering its initial level, and contemporaneously the spring water flow reduced.

In June 2016, an event of unrest consisting of ground subsidence on the western and southern sides of the Prà di Lama lake started and lasted approximately 9 months, until February 2017. During this period fractures formed and progressively grew, increasing their throw to up to $70 \mathrm{~cm}$ and affecting a large area on the western side of the lake (Figs. 3 and S2). Subsidence around the lake resulted in an increase in the lake surface, in particular on the western side and in the formation of tensile fractures (Figs. 3 and S2). Unlike the 1996 events of unrest, no lake-level changes or increase in water flow were observed from the springs around the lake.

\subsection{InSAR}

InSAR is ideally suited to monitor localized ground deformation such as that caused by sinkholes, as it can observe rapidly evolving deformation of the ground at high spatial
Table 1. Description of the activity at Prà di Lama lake.

\begin{tabular}{|c|c|}
\hline Year & Brief description of the event \\
\hline 991 & Seasonal pool fed by springs. \\
\hline 1828 & $\begin{array}{l}\text { Bursts of the spring water flow. Uprising of muddy } \\
\text { waters and clays (Raffaelli, 1869; De Stefani, } \\
\text { 1879). }\end{array}$ \\
\hline 1843 & $\begin{array}{l}\text { Bursts of the spring water flow. Uprising of muddy } \\
\text { waters and clays (Raffaelli, 1869; De Stefani, } \\
\text { 1879). }\end{array}$ \\
\hline 1876 & Subsidence and fracturing (De Stefani, 1879). \\
\hline 1877 & Subsidence and fracturing (De Stefani, 1879). \\
\hline 1962 & $\begin{array}{l}\text { Bursts of the spring water flow. Uprising of muddy } \\
\text { waters and clays (Giovannetti, 1975). }\end{array}$ \\
\hline 1969 & $\begin{array}{l}\text { Abrupt falling of the water level and fracturing } \\
\text { along the shores. The lake almost disappeared (Gio- } \\
\text { vannetti, 1975). }\end{array}$ \\
\hline 1985 & Arising of muddy waters in a well. \\
\hline 1996 & $\begin{array}{l}\text { Abrupt fall of the water level and fracturing along } \\
\text { the shores. }\end{array}$ \\
\hline 2016-2017 & Subsidence and fracturing. \\
\hline
\end{tabular}

resolution (Baer et al., 2002; Castañeda et al., 2009; Atzori et al., 2015; Abelson et al., 2017). Furthermore, the availability of relatively long data sets of SAR images in the Apennines allows us to study the behaviour of the Prà di Lama sinkhole using multi-temporal techniques. We processed a total of 200 interferograms using SAR images acquired by the ENVISAT satellite between 2003 to 2010 from two distinct tracks in ascending or descending viewing geometry 
(tracks 215 and 437). We used the Small BAseline Subset (SBAS) multi-interferogram method originally developed by Berardino et al. (2002) and recently implemented for parallel computing processing (P-SBAS) by Casu et al. (2014) to obtain incremental and cumulative time series of InSAR line-of-sight (LOS) displacements as well as maps of average LOS velocity. In particular, the InSAR processing has been carried out via the ESA platform P-SBAS open-access online tool named G-POD (Grid Processing On Demand) that allows ground displacement time series to be generated from a set of SAR data (De Luca et al., 2015).

The P-SBAS G-POD tool allows the user to set some key parameters to tune the InSAR processing. In this work, we set a maximum perpendicular baseline (spatial baseline) of $400 \mathrm{~m}$ and maximum temporal baseline of 1500 days. The geocoded pixel dimension was set to $\sim 80 \mathrm{~m}$ by $80 \mathrm{~m}$ (corresponding to averaging together 20 pixels in range and 4 pixels in azimuth).

We initially set a coherence threshold to 0.8 ( 0 to 1 for low to high coherence) in order to select only highly coherent pixels in our interferograms. The 0.8 coherence threshold is used to select the pixels for the phase unwrapping step that is carried out by the extended minimum cost flow (EMCF) algorithm (Pepe and Lanari, 2006). By setting high values of this parameter the pixels in input to the EMCF algorithm are affected by less noise compared to selecting low values, thus increasing the quality of the phase unwrapping step itself and reducing the noise in our final velocity maps and time series (De Luca et al., 2015; Cignetti et al., 2016).

We also inspected the series of interferograms and excluded individual interferograms with low coherence. We identified and discarded 29 noisy interferograms in track 215A and other 11 interferograms in track 437D. Finally, we applied an atmospheric phase screen (APS) filtering to mitigate further atmospheric disturbances (Hanssen, 2001). Accordingly, we used a triangular temporal filter with a width of 400 days to minimize temporal variations shorter than about a year as we focus on steady deformations rather than seasonal changes. A shorter time interval of 300 days was also tested but provided more noisy time series.

The average velocity map and the incremental time series of deformation obtained with the P-SBAS method have to be referred to a stable reference point. For our analysis, the reference point was initially set in the city of Massa because GPS measurements from Bennett et al. (2012) show that the surface velocities there are $<1 \mathrm{~mm} \mathrm{yr}^{-1}$; therefore, Massa can be considered stable. Assuming Massa as a reference point, the average velocity map revealed the deformation pattern around the Prà di Lama lake. We then moved the reference point outside the sinkhole deformation pattern but close to the village of Pieve Fosciana (Fig. S3a). Selecting a reference point close to our study area rather than in Massa allowed us to better minimize the spatially correlated atmospheric artefacts.
As a final post-processing step we also calculated the vertical and east-west components of the velocity field in the area covered by both the ascending and descending tracks and assuming no north-south displacement. Given that the study area is imaged by the ENVISAT satellite from two symmetrical geometries with similar incidence angles (few degrees of difference), the vertical and east-west components of the velocity field can simply be obtained solving the following system of equations (Manzo et al., 2006):

$$
\left\{\begin{array}{l}
v_{\mathrm{H}}=\frac{\cos \vartheta}{\sin (2 \vartheta)}\left(v_{\mathrm{DESC}}-v_{\mathrm{ASC}}\right)=\frac{v_{\mathrm{DESC}}-v_{\mathrm{ASC}}}{2 \sin \vartheta} \\
v_{\mathrm{V}}=\frac{\sin \vartheta}{\sin (2 \vartheta)}\left(v_{\mathrm{DESC}}+v_{\mathrm{ASC}}\right)=\frac{v_{\mathrm{DESC}}+v_{\mathrm{ASC}}}{2 \cos \vartheta},
\end{array}\right.
$$

where $v_{\mathrm{H}}$ and $v_{\mathrm{V}}$ are the horizontal and vertical component of the velocity field, $v_{\mathrm{DESC}}$ and $v_{\mathrm{ASC}}$ are the average LOS velocities in the descending and ascending tracks, respectively; $\vartheta$ is the incidence angle.

The InSAR P-SBAS analysis shows that significant surface deformation occurs at Pieve Fosciana between 2003 and 2010. The observed deformation pattern consists of a range increase mainly on the western flank of the Prà di Lama lake. The range increase is observed in both ascending and descending velocity maps (Fig. 4a, b), with average LOS velocities of up to $-7.1 \mathrm{~mm} \mathrm{yr}^{-1}$ decaying to $-1 \mathrm{~mm} \mathrm{yr}^{-1}$ over a distance of $400 \mathrm{~m}$ away from the lake. Elsewhere around the lake coherence is not kept due to the presence of both cropland and woodland cover, leading to decorrelation. However, few coherent pixels are identified on the eastern flank of the lake, in areas with buildings and sparse vegetation cover, suggesting that the deformation pattern may be circular, with a radius of $\sim 600 \mathrm{~m}$ (Figs. 4 and 5). In order to increase the number of analysed pixels we tested decreasing our coherence threshold from 0.8 to 0.4 . The results are displayed in Fig. S3b and show that only a few more pixels are gained north of the sinkhole compared to choosing a threshold of 0.8 (Fig. 4). We conclude that decreasing the coherence threshold does not allow the entire deformation pattern to be retrieved, likely due to the fact the area is vegetated.

The maps of vertical and east-west velocities show vertical rates of $-4.6 \mathrm{~mm} \mathrm{yr}^{-1}$ and horizontal eastward velocities of $5.4 \mathrm{~mm} \mathrm{yr}^{-1}$ (Fig. 4c, d) consistent with subsidence and contraction centred at the lake. Furthermore, Fig. 5 shows that the current deformation pattern follows the topography, suggesting that subsidence at Prà di Lama is a long-term feature. The time series of cumulative LOS displacements show that subsidence occurred at an approximately constant rate between the 2003 and the 2008 but it slowed down in 2008 (Fig. 4e, f), indicating that subsidence at Prà di Lama occurs also between events of unrest. Furthermore, our time series of vertical and east-west cumulative displacements also confirm that the fastest subsidence and contemporaneous eastward motion occurred until 2008 (Fig. 4g, h). In order to better understand the mechanisms responsible for the sink- 
(a)

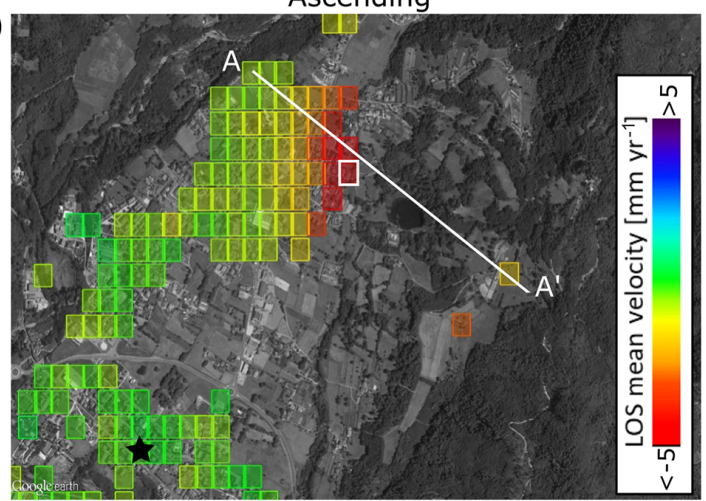

Vertical

(c)

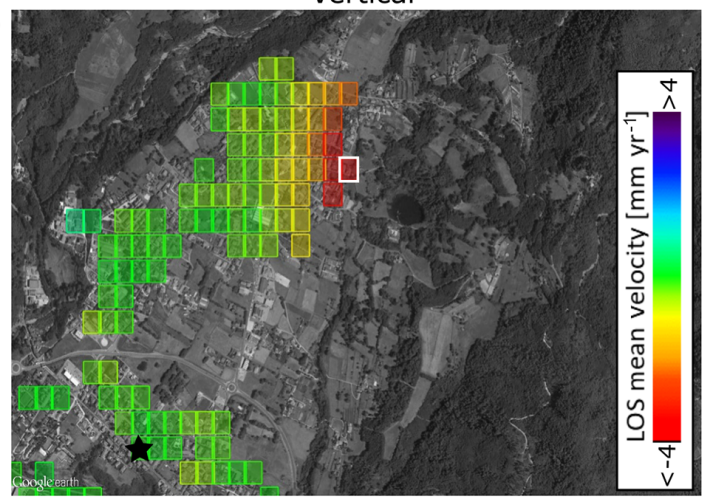

(e)

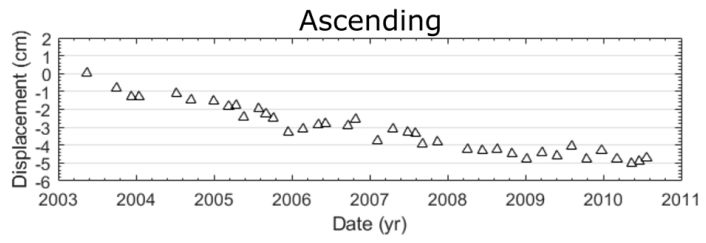

(g)

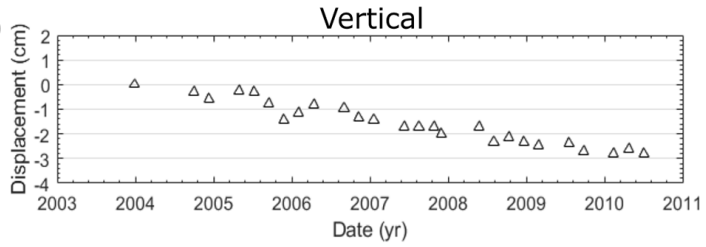

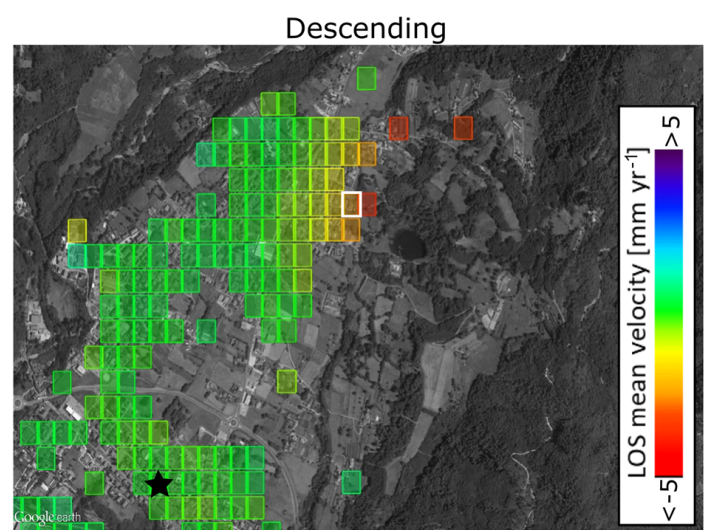

$\mathrm{EW}$

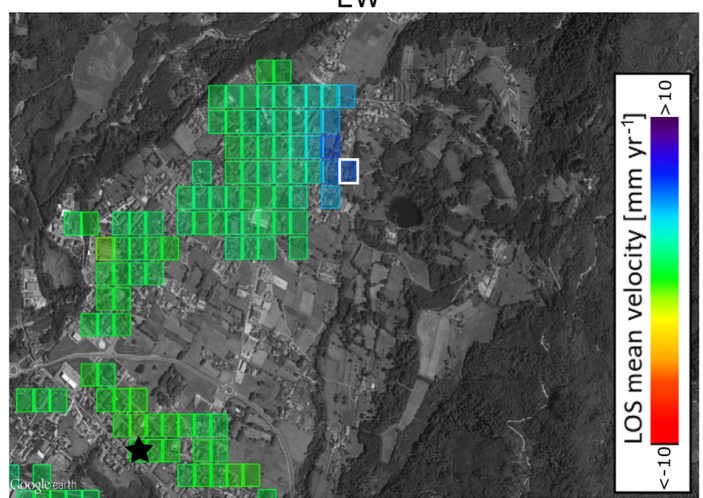

(d)

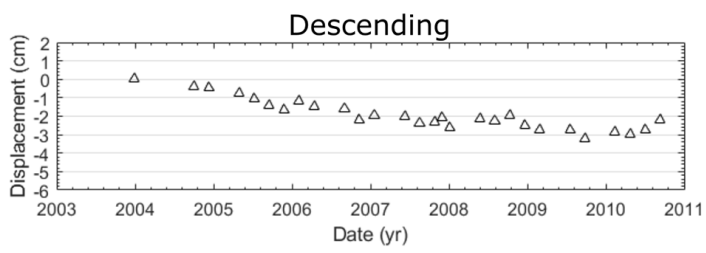

(f)

(h)

Figure 4. (a, b) Maps of average surface velocity and its vertical (c) and east-west (d) components obtained from ENVISAT SAR images acquired between 2003 and 2010. Negative values indicate a range increase. The white line in panel (a) marks the cross section shown in Fig. 4. The black star is the point used as a reference for the InSAR-SBAS processing. (e-h) Time series of incremental deformation extracted from the pixel bounded with the white rectangle.

hole growth and the different types of episodic unrest we also analysed the seismicity.

\subsection{Seismicity}

Seismicity at the Prà di Lama lake was analysed using the catalogue ISIDe (Italian Seismological Instrumental and Parametric Data-Base) spanning the time period from 1986 to 2016. We calculated the cumulative seismic moment release using the relation between seismic moment and magnitudes given by Kanamori (1977). First, we analysed the seis- mic moment release and the magnitude content of the earthquakes in the area encompassing the sinkhole and the fault intersection (10 km radius, Fig. 1) to understand whether unrest at Prà di Lama is triggered by earthquakes along the active faults (Fig. 6). Figure 6a shows that, although several seismic swarms occurred in the area, no clear temporal correlation between the swarms and the events of unrest at Prà di Lama is observed, suggesting that the majority of seismic strain released on faults around the Prà di Lama lake does not affect the activity of the sinkhole. We removed from the 


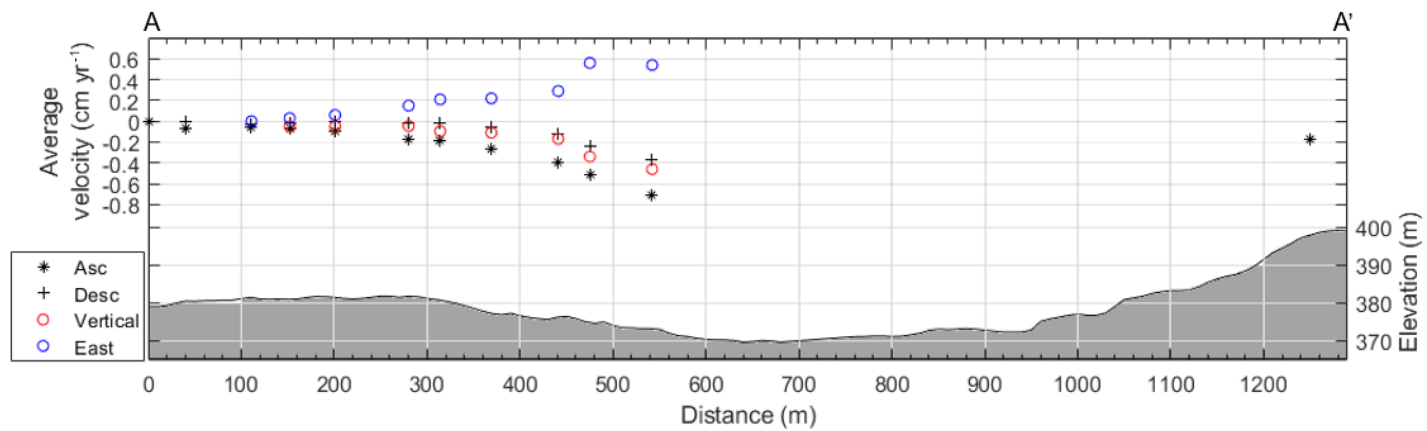

Figure 5. Cross section of topography and InSAR velocities along the A-A' profile as shown in Fig. $3 \mathrm{a}$.

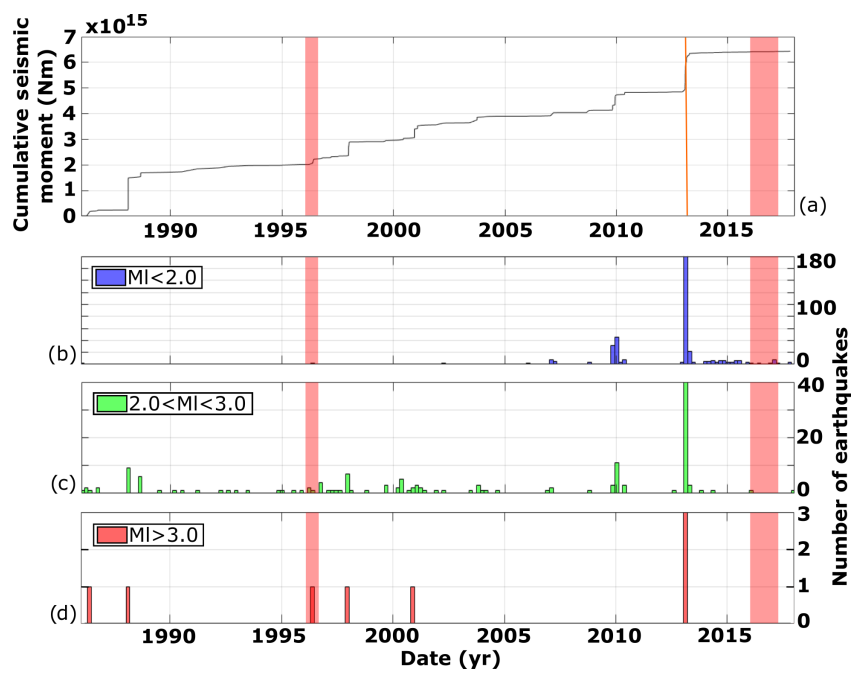

Figure 6. Seismicity of an area $10 \mathrm{~km}$ in radius around the Prà di Lama lake. Cumulative seismic moment released in the area (a) and histograms of the number of earthquakes per month. Three different classes of magnitude have been created: $M_{1}<2.0$ (b), $2.0<M_{1}<$ 3.0 (c) and $M_{1}>3.0$ (d). The data set covers the period between 1986 and 2017. The red transparent bars indicate the two events of unrest of 1996 and 2016. The orange solid line in panel (a) marks the $M_{\mathrm{W}} 4.8$ earthquake, on 25 January 2013.

plot in Fig. 6a the high-magnitude earthquake, $M_{\mathrm{w}} 4.8$, on the 25 January 2013 in order to better visualize the pattern of seismic moment release in time. In any case, no activity at Prà di Lama was reported in January 2013.

We also analysed the local seismicity around the Prà di Lama lake, within a circular area of $3 \mathrm{~km}$ radius around the lake (Fig. 1) to better understand the deformation processes occurring at the sinkhole and we found that swarms of lowmagnitude earthquakes $\left(M_{1} \leq 2\right)$ occurred during both events of unrest at Prà di Lama in 1996 and 2016 (Fig. 7a, b, c), while a few earthquakes with magnitudes $>2$ occurred irrespective of the events of unrest. This indicates that seismicity during sinkhole activity is characterized by seismic energy released preferentially towards the lower end of the

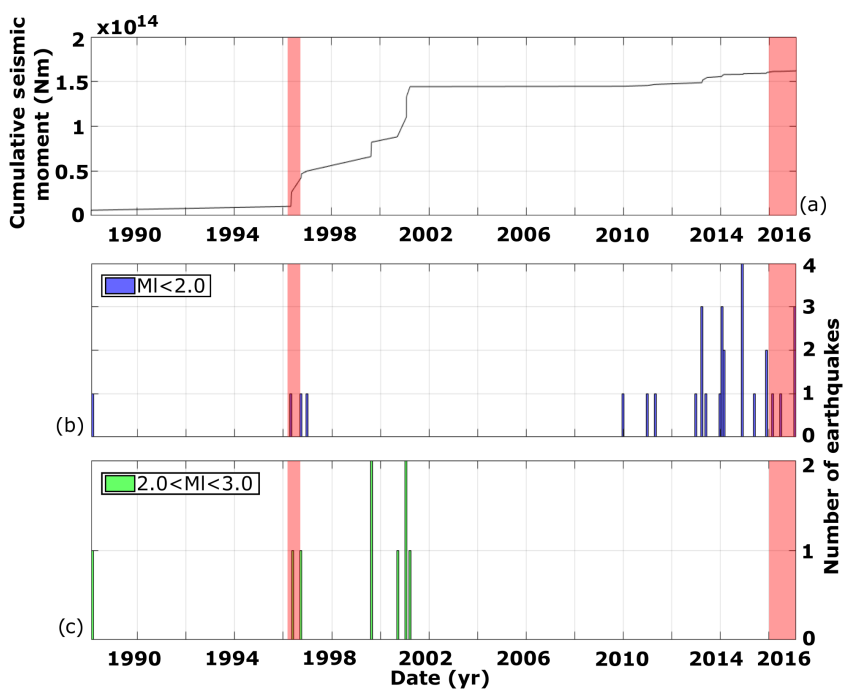

Figure 7. Seismicity of an area $3 \mathrm{~km}$ in radius around the Prà di Lama lake. Plot of the cumulative seismic moment released in the area (a) and histograms showing the number of earthquakes occurred each month. Two different classes of magnitude have been created: $M_{1}<2.0$ (b), $2.0<M_{1}<3.0$ (c). No events of $M_{1}>3.0$ occurred in the area between 1986 and 2017. The red transparent bars indicate the two events of unrest of 1996 and 2016.

magnitude spectrum. This pattern is specific to the sinkhole area, because in the broader region (Fig. 6b, c) the majority of earthquake magnitudes are in the range $M_{1}>2$ to $M_{1}<3$ and few with $M_{1}>3$ also occurred. We also analysed the hypocentres of the earthquakes around the Prà di Lama lake ( $3 \mathrm{~km}$ radius) and find that these range between 4.5 and $11.5 \mathrm{~km}$ depth, indicating that deformation processes in the fault zone control the sinkhole activity. On the other hand, no earthquakes were recorded at Prà di Lama during the period of subsidence identified by InSAR between 2003 and 2010, indicating that subsidence between events of unrest continues largely aseismically.

To strengthen our seismicity analysis and clarify whether a connection between major tectonic earthquakes and sinkhole unrest exists, we also analysed the historical parametric seis- 


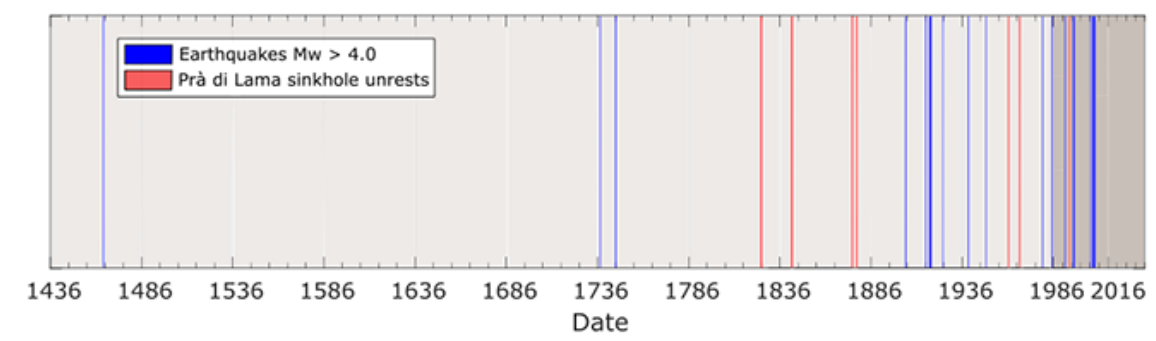

Figure 8. Comparison between the earthquakes (blue lines) in the Garfagnana area (INGV Catalogo Paramentrico dei Terremoti Italiani CPTI15, Rovida et al., 2016) and events of unrest at the Prà di Lama sinkhole (red lines). Light grey shading marks the time period covered by CPT15, while dark grey shading is the period covered by ISIDe.

mic catalogues (Rovida et al., 2016; INGV Catalogo Parametrico dei Terremoti Italiani, CPTI15). Figure 8 shows the occurrence of major earthquakes, with magnitude $>4.0$ up to $20 \mathrm{~km}$ away from Pieve Fosciana and the events of sinkhole unrest at Prà di Lama. No clear connection between occurrence of large distant earthquakes and events of sinkhole unrest is observed, suggesting that the mechanisms responsible for the activation of the Prà di Lama sinkhole should be attributed to local processes.

\section{Discussion and conclusions}

A multi-disciplinary data set of InSAR measurements, field observations and seismicity reveal that diverse deformation events occur at the Prà di Lama sinkhole. Two main events of sinkhole unrest occurred at Prà di Lama in 1996 and 2016 but the processes had different features. In 1996 the lake level dropped together with increased water outflow from the springs, while in 2016 ground subsidence led to the expansion of the lake surface and fracturing. In 2016, fractures formed on the south-western shore of the lake. The main active strike-slip fault is also oriented SW, suggesting a possible tectonic control on the deformation.

We considered processes not related to the sinkhole activity that could explain the observed deformation at Prà di Lama. Active landslides can cause both vertical and horizontal surface motions (e.g. Nishiguchi et al., 2017). However, no landslides are identified in the deforming area around the sinkhole (Fig. 3). Furthermore, the low topographic slopes rule out the presence of active landslides in the area. Concentric deformation patterns are observed above shallow aquifers (e.g. Amelung et al., 1999). However, deformation caused by aquifers have a seasonal pattern rather than continuous subsidence over the timespan of several years, as in Prà di Lama. A long-term subsidence could only be caused by over-exploitation of an aquifer but no water is pumped from the aquifers in the deforming area around Prà di Lama. We conclude that the observed InSAR deformation is caused by the sinkhole.

InSAR analysis shows that continuous but aseismic subsidence of the sinkhole occurred between the two events of unrest, during the period 2003-2010. Instead swarms of lowmagnitude earthquakes coeval to the unrest events of 1996 and 2016 were recorded at depth between 4.5 and $11.5 \mathrm{~km}$, indicating that a link between low-magnitude seismicity and sinkhole activity exists. We suggest that seismic creep in the fault zone underneath Prà di Lama occurs, causing the diverse deformation events.

Seismic creep at depth could have induced pressure changes in the aquifer above the fault zone (1996 events) as well as causing subsidence by increased fracturing (2016 events). The seismicity pattern revealed by our analysis suggests that the Mt Perpoli-T. Scoltenna strike-slip fault system underneath Prà di Lama is locally creeping, producing seismic sequences of low-magnitude earthquakes. Similar seismicity patterns were observed along different active faults (i.e. Nadeau et al., 1995; Linde et al., 1996; Rau et al., 2007; Chen et al., 2008; Harris, 2017). In 2006, along the Superstition Hills fault (San Andreas fault system, California) seismic creep has been favoured by high water pressure (Scholz, 1998; Wei et al., 2009; Harris, 2017). We suggest that along the fault zone below Prà di Lama an increase in pressure in the aquifer in 1996 caused fracturing at the bottom of the lake and upward migration of fluids rich in clays, in agreement with the observations of lake-level drop and mud-rich water ejected by the springs in 1996. Our interpretation is also in agreement with geochemical data indicating that the high salinity of thermal waters at Prà di Lama have a deep origin, $\sim 2000 \mathrm{~m}$, where fluid circulation dissolves evaporites and carbonates, creating cavities and then reaching the surface by rapid upwelling along the faults system (Gherardi and Pierotti, 2018). The presence of deep cavities and a thick non-carbonate sequence suggests that the Prà di Lama sinkhole is a deep-sited caprock collapse sinkhole according to the sinkhole classification of Gutiérrez et al. (2008, 2014). Sudden fracturing and periods of compaction of cavities created by enhanced rock dissolution and upward erosion in the fluid circulation zone could explain both sudden subsidence and fracturing, as in 2016, and periods of continuous but aseismic subsidence as in 2003-2010. Similar processes have been envisaged for the formation of a sinkhole at the Napoleonville Salt Dome, where a seismicity study suggests 
that fracturing enhanced the rock permeability, promoting the rising of fluids and, as a consequence, erosion and creation of deep cavities prone to collapse (Sibson, 1996; Micklethwaite et al., 2010; Nayak and Dreger, 2014; Yarushina et al., 2017). Recently, a sequence of seismic events was identified at Mineral Beach (Dead Sea fault zone) and was interpreted as the result of crack formations and faulting above subsurface cavities (Abelson et al., 2017).

Precursory subsidence of years to a few months has been observed to precede sinkhole collapse in carbonate or evaporitic bedrocks (e.g. Baer et al., 2002; Nof et al., 2013; Cathleen and Bloom, 2014; Atzori et al., 2015; Abelson et al., 2017). However, the timing of these processes strongly depends on the rheological properties of the rocks (Shalev and Lyakhovsky, 2012). Furthermore, the presence of a thick lithoid sequence in Prà di Lama may delay sinkhole collapse, also in agreement with the exceptionally long timescale (since AD 991) of growth of the Prà di Lama sinkhole (Shalev and Lykovsky, 2012; Abelson et al., 2017). However, at present we are not able to establish if and when a major collapse will occur in Prà di Lama.

We identified a wide range of surface deformation patterns associated with the Prà di Lama sinkhole and we suggest that a source mechanism for the sinkhole formation and growth is seismic creep in the active fault zone underneath the sinkhole. This mechanism could control the evolution of other active sinkholes in Italy as well as in other areas worldwide where sinkhole form in active fault systems (e.g. Dead Sea area). InSAR monitoring has already been shown to be a valid method to detect precursory subsidence occurring before a sinkhole collapse and the recent SAR missions, such as the European Sentinel-1, will very likely provide a powerful tool to identify such deformations.

Data availability. The DEM data used in this study are from the SRTM (Shuttle Radar Topography Mission) by JPL (NASA) and accessible at https://earthexplorer.usgs.gov (USGS, 2018). The lidar DEM data were taken from Regione Toscana through the GEOscopio webgis portal (http://www502.regione.toscana.it/geoscopio/ cartoteca.html; Regione Toscana, 2018). The seismicity data are provided by the Istituto Nazionale di Geofisica e Vulcanologia (INGV) through the Italian Seismological Instrumental and Parametric Data-Base (ISIDe; INGV, 2016) and the Catalogo Parametrico dei Terremoti Italiani 2015 (CPTI15) (Rovida et al., 2016).

Supplement. The supplement related to this article is available online at: https://doi.org/10.5194/nhess-18-2355-2018-supplement.

Author contributions. ALR, CP and GM planned the work. ALR drafted the manuscript and prepared the figures with input from all other authors. Previously unpublished historical data from Prà di Lama were collected by AP. ALR processed the InSAR data under the guidance of FC and CDL. ALR and CP analysed the seismic data. ALR, GM and AP collected structural data around the lake from the 2016 event. GD'AA and GM provided the geological, geomorphological and structural data of the Garfagnana area.

Competing interests. The authors declare that they have no conflict of interest.

Acknowledgements. We thank the two anonymous reviewers for their constructive and useful comments. We thank the European Space Agency (ESA) for providing the ENVISAT SAR data used in this study through the VA4. This work was partially supported by the ESA G-POD and GEP projects. Part of the post-processing was carried out at IREA-CNR through the Infrastructure of High Technology for Environmental and Climate Monitoring project for Structural improvement (I-AMICA-PONa3_00363) financed under the National Operational Programme (NOP) for "Research and Competitiveness 2007-2013" and co-funded by European Regional Development Fund (ERDF) and national resources. All processed interferograms are archived at IREA-CNR, Naples. Alessandro La Rosa thanks IREA-CNR, Naples for his InSAR training internship. Carolina Pagli gratefully acknowledges the support she received through her Rita Levi Montalcini fellowship (MIUR Montalcini 26259_21/12/2013). This work was also financially supported by Università di Pisa.

Edited by: Mario Parise

Reviewed by: two anonymous referees

\section{References}

Abelson, M., Aksinenko, T., Kurzon, I., Pinsky, V., Baer, G., Nof, R., and Yechieli, Y.: Nanoseismicity forecast sinkhole collapse in the Dead Sea coast years in advance, Geology, 46, 83-86, https://doi.org/10.1130/G39579.1, 2017.

Amelung, F., Galloway, D. L., Bell, J. W., Zebker, H. A., and Laczniak, R. J.: Sensing the ups and downs of Las Vegas: InSAR reveals structural control of land subsidence and aquifer-system deformation, Geology, 27, 483-486, https://doi.org/10.1130/00917613(1999)027<0483:STUADO>2.3.CO;2, 1999.

Atzori, S., Baer, G., Antonioli, A., and Salvi, S.: InSARbased modelling and analysis of sinkholes along the Dead Sea coastline, Geophys. Res. Lett., 42, 8383-8390. https://doi.org/10.1002/2015GL066053, 2015.

Baer, G., Schattner, U., Wachs D., Sandwell, D., Wdowinski, S., and Frydman, S.: The lowest place on Earth is subsiding - An InSAR (Interferomeric Synthetic Aperture Radar) Perspective, Geol. Soc. Am. Bull., 114, 12-23, https://doi.org/10.1130/00167606(2002)114<0012:TLPOEI>2.0.CO;2, 2002.

Baldacci, F., Botti, F., Cioni, R., Molli, G., Pierotti, L., Scozzari, A., and Vaselli, L.: Geological-structural and hydrogeochemical studies to identify sismically active structures: case history from the Equi Terme-Monzone hydrothermal system (Northern Apennine - Italy), Geoitalia, 6th Italian Forum of Earth Sciences, 1214 September 2007, Rimini, Italy, 2007.

Bencini, A., Duchi, V., and Martini, M.: Geochemistry of thermal springs of Tuscany (Italy), Chem, Geol,, 19, 229-252, 1977. 
Bennet, R. A., Serpelloni, E., Hreinsdottir, S., Brandon, M. T., Buble, G., Basic T., Casale, G., Cavaliere, A., Anzidei, M., Marjonovic, M., Minelli, G., Molli, G., and Montanari, A.: Synconvergent extension observed using the RETREAT GPS network, northern Apennines, Italy, J. Geophys. Res., 117, B04408, https://doi.org/10.1029/2011JB008744, 2012.

Berardino, P., Fornaro, G., Lanari, R., and Sansosti, E.: A new algorithm for surface deformation monitoring based on Small Baseline Differential SAR interferograms, Int. Geosci. Remote Se., 40, 2375-2383, https://doi.org/10.1109/TGRS.2002.803792, 2002.

Bonini, M., Corti, G., Donne, D. D., Sani, F., Piccardi, L., Vannucci, G., Genco, R., Martelli, L., and Ripepe, M.: Seismic sources and stress transfer interaction among axial normal faults and external thrust fronts in the northern Apennines (Italy): a working hypothesis based on the 1916-1920 time-space cluster of earthquakes, Tectonophysics, 680, 67-89, https://doi.org/10.1016/j.tecto.2016.04.045, 2016.

Buchignani, V., D’Amato Avanzi, G., Giannecchini, R., and Puccinelli, A.: Evaporite karst and sinkholes: a synthesis on the case of Camaiore (Italy), Environ. Geol., 53, 1037-1044, https://doi.org/10.1007/s00254-007-0730-x, 2008.

Caramanna, G., Ciotoli, G., and Nisio, S.: A review of natural sinkhole phenomena in Italian plain areas, Nat. Hazards, 45, 145172, https://doi.org/10.1007/s11069-007-9165-7, 2008.

Castañeda, C., Gutiérrez, F., Manunta, M., and Galve, J. P.: DInSAR measurements of ground deformation by sinkholes, mining subsidence, and landslides, Ebro River, Spain, Earth Surf. Proc. Land., 34, 1562-1574, https://doi.org/10.1002/esp.1848, 2009.

Casu, F., Elefante, S., Imperatore, P., Zinno, I., Manunta, M., De Luca, C., and Lanari, R: SBAS-DInSAR parallel processing for deformation time-series computation, IEEE J. Sel. Top. Appl., 7, 3285-3296, https://doi.org/10.1109/JSTARS.2014.2322671, 2014.

Cathleen, J. and Blom, R.: Bayou Corne, Louisiana, sinkhole: Precursory deformation measured by radar interferometry, Geology, 42, 111-114, https://doi.org/10.1130/G34972.1, 2014.

Chen, K. H., Nadeau, R. M., and Rau, R.: Characteristic repeating earthquakes in an arc-continent collision boundary zone: The Chihshang fault of eastern Taiwan, Earth Planet. Sc. Lett., 276, 262-272, https://doi.org/10.1016/j.epsl.2008.09.021, 2008.

Cignetti, M., Manconi, A., Manunta, M., Giordan, D., De Luca, C., Allasia, P., and Ardizzone, F.: Taking Advantage of the ESA GPOD Service to Study Ground Deformation Processes in High Mountain Areas: A Valle d'Aosta Case Study, Northern Italy, Remote Sensing, 8, 852, https://doi.org/10.3390/rs8100852, 2016.

Closson, D.: Structural control of sinkholes and subsidence hazards along the Jordanian Dead Sea coast, Environ. Geol., 47, 290301, https://doi.org/10.1007/s00254-004-1155-4, 2005.

Closson, D., Karaki, N. A., Klinger, Y., and Hussein, M. J.: Subsidence and Sinkhole Hazard Assessment in the Southern Dead Sea Area, Jordan, Pure Appl. Geophys., 162, 221-248, https://doi.org/10.1007/s00024-004-2598-y, 2005.

Del Prete, S., Iovine, G., Parise, M., and Santo, A.: Origin and distribution of different types of sinkholes in the plain areas of Southern Italy, Geodin. Acta, 23, 113-127, https://doi.org/10.3166/ga.23.113-127, 2010.

De Luca, C., Cuccu, R., Elefante, S., Zinno, I., Manunta, M., Casola, V., Rivolta, G., Lanari, R., and Casu, F.: An On-Demand
Web Tool for the Unsupervised Retrieval of Earth's Surface Deformation from SAR Data: The P-SBAS Service within the ESA G-POD Environment, Remote Sensing, 7, 15630-15650, https://doi.org/10.3390/rs71115630, 2015.

De Stefani, C.: Le Acque Termali di Pieve Fosciana, Memorie della Società Toscana di Scienze Naturali, 4, 72-97, 1879.

Di Naccio, D., Boncio, P., Brozzetti, F., Pazzaglia, F. J., and Lavecchia, G.: Morphotectonic analysis of the Lunigiana and Garfagnana grabens (northern Apennines, Italy): Implications for active normal faulting, Geomorphology, 201, 293-311, https://doi.org/10.1016/j.geomorph.2013.07.003, 2013.

Doglioni, C.: A proposal for the kinematic modelling of the W-dipping subduction - possible applications to the Tyrrhenian-Apennines system, Terra Nova, 3, 423-434, https://doi.org/10.1111/j.1365-3121.1991.tb00172.x, 1991.

Elter, P., Giglia, G., Tongiorgi, M., and Trevisan, L.: Tensional and compressional areas in the recent (Tortonian to Present) evolution of the Northern Apennines, B. Geofis. Teor. Appl., 42, 3-18, 1975.

Faccenna, C., Florindo, F., Funiciello, R., and Lombardi, S.: Tectonic setting and Sinkhole Features: case histories from Western Central Italy, Quat. Proc., 3, 47-56, 1993.

Faccenna, C., Becker, T. W., Auer, L., Billi, A., Boschi, L., Brun, J., Capitanio, F. A., Funiciello, F., Horvàth, F., Jolivet, L., Piromallo, C., Royden, L., Rossetti, F., and Serpelloni, E.: Mantle dynamics in the Mediterranean, Rev. Geophys., 52, 28-332, https://doi.org/10.1002/2013RG000444, 2014.

Florea, L. J.: Using State-wide GIS data to identify the coincidence between sinkholes and geologic structure, J. Cave Karst Stud., 67, 120-124, 2005.

Ford, D. C. and Williams, P.: Karst Hydrogeology and Geomorphology, Wiley, Chichester, UK, 562 pp., 2007.

Frumkin, A. and Raz, E.: Collapse and subsidence associated with salt karstification along the Dead Sea, Carbonate. Evaporite., 16, 117-130, https://doi.org/10.1007/bf03175830, 2001.

Gherardi, F. and Pierotti, L.: The suitability of the Pieve Fosciana hydrothermal system (Italy) as a detection site for geochemical seismic precursors, Appl. Geochem., 92, 166-179, https://doi.org/10.1016/j.apgeochem.2018.03.009, 2018.

Giovannetti, F.: Pieve Fosciana Ieri e Oggi, Amministrazione comunale di Pieve Fosciana, Lucca, Italy, 51 pp., 1975.

Gutierréz, F., Guerrero, J., and Lucha, P.: A genetic classification of sinkholes illustrated from evaporite paleokarst exposures in Spain, Environ. Geol., 53, 993-1006, https://doi.org/10.1007/s00254-007-0727-5, 2008.

Gutierréz, F., Parise, M., De Waele J., and Jourde, H.: A review on natural and human-induced geohazards and impacts in karst, Earth-Sci. Rev., 138, 61-88, https://doi.org/10.1016/j.earscirev.2014.08.002, 2014.

Hanssen, R. F.: Radar Interferometry: Data Interpretation and Error Analysis, Kluwer Academic Publisher, https://doi.org/10.1007/0-306-47633-9, 2001.

Harris, R. A.: Large earthquakes and creeping faults, Rev. Geophys., 55, 169-198, https://doi.org/10.1002/2016RG000539, 2017.

Harrison, R. W., Newell, W. L., and Necdet, M.: Karstification Along an Active Fault Zone in Cyprus, U.S. Geological Survey Water-Resources Investigations Report 02-4174, Atlanta, Georgia, USA, 2002. 
Istituto Nazionale di Geofisica e Vulcanologia (INGV): Italian Seismological Instrumental and Parametric Data-Base, ISIDe working group, version 1.0, https://doi.org/10.13127/ISIDe, 2016.

Johnson, A. G., Kovach, R. L., and Nur, A.: Pore pressure changes during creep events on the San Andreas Fault, J. Geophys. Res., 78, 851-857, https://doi.org/10.1029/JB078i005p00851, 1973.

Kanamori, H.: The Energy Release in Great Earthquakes, J. Geophys. Res., 82, 2981-2987, https://doi.org/10.1029/JB082i020p02981, 1977.

Kawashima, K., Aydan, O., Aoki, T., Kishimoto, I., Konagal, K., Matsui, T., Sakuta, J., Takahashi, N., Teodori, S.-P., and Yashima, A.: Reconnaissance investigation on the damage of the 2009 L'Aquila, Central Italy earthquake, J. Earthq. Eng., 14, 817-841, https://doi.org/10.1080/13632460903584055, 2010.

Le Breton, E., Handy, M., Molli, G., and Ustaszewski K.: Post-20 Ma Motion of the Adriatic Plate: New Constraints from Surrounding Orogens and Implications for Crust-Mantle Decoupling, Tectonics, 36, 3135-3154, https://doi.org/10.1002/2016TC004443, 2017.

Linde, A. T., Gladwin, M. T., Johnston, M. J. S., Gwyther, R. L., and Bilham, R. G.: A slow earthquake sequence on the San Andreas fault, Nature, 383, 65-68, https://doi.org/10.1038/383065a0, 1996.

Manzo, M., Ricciardi, G. P., Casu F., Ventura, G., Zeni, G., Borgström S., Berardino, P., Del Gaudio, C., and Lanari, R.: Surface deformation analysis in th Ischia Island (Italy) based on spaceborne radar interferometry, J. Volcanol. Geoth. Res., 151, 399-416, https://doi.org/10.1016/j.jvolgeores.2005.09.010, 2006.

Meletti, C., Patacca, E., and Scandone P.: Construction of a Seismotectonic Model: The Case of Italy, Pure Appl. Geophys., 157, 11-35, https://doi.org/10.1007/PL00001089, 2000.

Micklethwaite, S., Sheldon, H. A., and Baker, T.: Active fault and shear processes and their implications for mineral deposit formation and discovery, J. Struc. Geol., 32, 151-165, https://doi.org/10.1016/j.jsg.2009.10.009, 2010.

Molli, G., Torelli, L., and Storti, F.: The 2013 Lunigiana (Central Italy) earthquake: Seismic source analysis from DInSar and seismological data, and geodynamic implications for the northern Apennines. A discussion, Tectonophysics, 668-669, 108-112, https://doi.org/10.1016/j.tecto.2015.07.041, 2016.

Molli, G., Pinelli, G., Bigot, A., Bennett, R., Malavieille, J., and Serpelloni, E.: Active Faults in the inner northern Apennines: a multidisciplinary reappraisal. From 1997 to 2016: Three Destructive Earthquakes along the Central Apennnine Fault system, Camerino, Italy, 19-22 July 2017, Abstract Volume, p. 29, 2017.

Nadeau, R. M., Foxal, W., and McEvilly, T. V.: Clustering and Periodic Recurrence of Microearthquakes on the San Andreas Fault at Parkfield, California, Science, 267, 503-507, https://doi.org/10.1126/science.267.5197.503, 1995.

Nayak, A. and Dreger, D. S.: Moment Tensor Inversion of Seismic Events Associated with the Sinkhole at Napoleonville Salt Dome, Louisiana, B. Seismol. Soc. Am., 104, 1763-1776, https://doi.org/10.1785/0120130260, 2014.

Nishiguchi, T., Tsuchiya, S., and Imaizumi, F.: Detection and accuracy of landslide movement by InSAR analysis using PALSAR-2 data, Landslides, 14, 1483-1490, https://doi.org/10.1007/s10346-017-0821-z, 2017.
Nisio, S.: The sinkholes in the Tuscany Region, in: Natural sinkhole phenomena in the Italian plain area, Memorie descrittive della carta geologica d'Italia, 85, Istituto Superiore per la Protezione e la Ricerca Ambientale, Servizio Geologica d'Italia, 213-268, available at: http://www.isprambiente.gov.it/it/pubblicazioni/periodicitecnici/memorie-descrittive-della-carta-geologica-ditalia/ifenomeni-naturali-di-sinkhole-nelle-aree-di (last access: 11 September 2018), 2008.

Nof, R. N., Baer, G., Ziv, A., Raz, E., Atzori, S., and Salvi, S.: Sinkhole precursors along the Dead Sea, Israel, revealed by SAR interferometry, Geology, 41, 1019-1022, https://doi.org/10.1130/G34505.1, 2013.

Parise, M. and Vennari, C.: A chronological catalogue of sinkholes in Italy: the first step toward a real evaluation of the sinkhole hazard, in: Sinkholes and the Engineering and Environmental Impacts of Karst: Proceedings of the Thirteenth Multidisciplinary Conference, edited by: Land, L., Doctor, D. H., and Stephenson, J. B., NCKRI Symposium 2, 6-10 May 2013, Carlsbad, New Mexico, USA, National Cave and Karst Research Institute, Carlsbad (NM), https://doi.org/10.5038/9780979542275.1149, 2013.

Parise, M., Perrone, A., Violante, C., Stewart, J. P., Simonelli, A., and Guzzetti, F.: Activity of the Italian National Research Council in the aftermath of the 6 April 2009 Abruzzo earthquake: the Sinizzo Lake case study, Proc. 2nd Int Workshop "Sinkholes in the Natural and Anthropogenic Environment”, 3-4 December 2009, Rome, Italy, 623-641, https://doi.org/10.13140/2.1.3094.1127, 2010.

Patacca, E. and Scandone, P.: Post-Tortonian mountain building in the Apennines, the role of the passive sinking of a relic lithospheric slab, in: The Lithosphere in Italy, Advances in Earth Science Research, 5-6 May 1987, Rome, Itlay, 157-176, 1989.

Pepe, A. and Lanari, R.: On the extension of the minimum cost flow algorithm for phase unwrapping of multitemporal differential SAR interferograms, IEEE T. Geosci. Remote, 44, 2374 2383, https://doi.org/10.1109/TGRS.2006.873207, 2006.

Pezzo, G., Boncori, J. P. M., Atzori, S., Piccinini, D., Antonioli, A., and Salvi, S.: The 2013 Lunigiana (Central Italy) earthquake: Seismic source analysis from DInSAR and seismological data, and geodynamical implications for the northern Apennines, Tectonophysics, 636, 315-324, https://doi.org/10.1016/j.tecto.2014.09.005, 2014.

Pinelli, G.: Tettonica recente e attiva nell'Appennino interno a Nord dell'Arno: una revisione delle strutture e delle problematiche, Diploma Thesis, Dipartimento di Scienze della Terra, Università di Pisa, Italy, 89 pp., 2013.

Raffaelli, R.: Sulle acque termali di Pieve Fosciana in Garfagnana, Memoria diretta al Consiglio Provinciale di Massa, Tipografia dei fratelli Nistri, Pisa, Italy, 23 pp., 1869.

Rau, R., Chen, K. H., and Ching, K.: Repeating earthquakes and seismic potential along the northern Longitudinal Valley fault of Taiwan, Geophys. Res. Lett., 34, L24301, https://doi.org/10.1029/2007GL031622, 2007.

Regione Toscana: GEOscopio, Direzione urbanistica e poitivhe abitative, Settore Sistema Informativo Territoriale ed Ambientale, available at: http://www502.regione.toscana.it/geoscopio/ cartoteca.html, last access: 11 September 2018. 
Rovida, A., Locati, M., Camassi, R., Lolli, B., and Gasperini, P. (Eds.): CPTI15, the 2015 version of the Parametric Catalogue of Italian Earthquakes, Istituto Nazionale di Geofisica e Vulcanologia, https://doi.org/10.6092/INGV.IT-CPTI15, 2016.

Salamon, A.: Seismically induced ground effects of the February $11,2004, M_{\mathrm{L}}=5.2$, North-eastern Dead Sea earthquake, The Ministry of National Infrastructures, Geological Survey of Israel, Open File Report GSI/30/04, 25 pp., available at: http://www. isprambiente.gov.it/files/progetti/inqua/report-final.pdf (last access: 11 September 2018), 2004.

Santo, A., Del Prete, S., Di Crescenzo, G., and Rotella, M.: Karst processes and slope instability: some investigations in the carbonate Apennine of Campania (southern Italy), in: Natural and Anthropogenic Hazards in Karst Areas: Recognition, Analysis, and Mitigation, edited by: Parise, M. and Gunn, J., Geological Society, London, 279, 59-72, https://doi.org/10.1144/SP279.6, 2007.

Scholz, C. H.: Earthquakes and friction laws, Nature, 391, 37-42, https://doi.org/10.1038/34097, 1998.

Serpelloni, E., Anzidei, M., Baldi, P., Casula, G., and Galvani, A.: Crustal velocity and strain -rate fields in Italy and surrounding regions: New results from the analysis of permanent and non-permanent GPS networks, Geophys. J. Int., 161, 861-880, https://doi.org/10.1111/j.1365-246X.2005.02618.x, 2005.

Shalev, E. and Lyakhovsky, V.: Viscoelastic damage modelling of sinkhole formation, J. Struct. Geol., 42, 163-170, https://doi.org/10.1016/j.jsg.2012.05.010, 2012.
Sibson, R. H.: Structural permeability of fluid-driven fault-fracture meshes. J. Struct. Geol., 18, 1031-1042, https://doi.org/10.1016/0191-8141(96)00032-6, 1996.

Stramondo, S., Vannoli, P., Cannelli, V., Polcari, M., Melini, D., Samsonov, S., Moro, M., Bignami, C., and Saroli, M.: X- and C-band SAR surface displacement for the 2013 Lunigiana earthquake (Northern Italy): a breached relay ramp?, IEEE J. Sel. Top. Appl., 7, 2746-2753, https://doi.org/10.1109/JSTARS.2014.2313640, 2014.

Tertulliani, A. and Maramai, A.: Macroseismic evidence and site effects for the Lunigiana (Italy) 1995 Earthquake, J.Seismol., 2, 209-222, https://doi.org/10.1023/A:1009734620985, 1998.

U.S. Geological Survey (USGS): EarthExplorer, U.S. Department of the Interior, available at: https://earthexplorer.usgs.gov, last access: 11 September 2018.

Wadas, S. H., Tanner, D. C., Polom, U., and Krawczyk, C. M.: Structural analysis of S-wave seismics around an urban sinkhole: evidence of enhanced dissolution in a strikeslip fault zone, Nat. Hazards Earth Syst. Sci., 17, 2335-2350, https://doi.org/10.5194/nhess-17-2335-2017, 2017.

Wei, M., Sandwell, D., and Fialko, Y.: A silent $M_{\mathrm{W}} 4.7$ slip event of October 2006 on the Superstition Hills fault, southern California, J. Geophys. Res., 114, B07402, https://doi.org/10.1029/2008JB006135, 2009.

Yarushina, V. M., Podladchikov, Y. Y., Minakov, A., and Räss, L.: On the Mechanisms of Stress-Triggered Seismic Events during Fluid Injection, in: Sixth Biot Conference on Poromechanics, 9-13 July 2017, Paris, France, 795-800, https://doi.org/10.1061/9780784480779.098, 2017. 